\title{
Neotectonics and seismicity of the southern margin of the Pannonian basin in Serbia
}

\author{
M. Marović ${ }^{1}$, I. Djoković ${ }^{1}$, L. Pešić ${ }^{1}$, S. Radovanović ${ }^{2}$, M. Toljić ${ }^{1}$, and N. Gerzina ${ }^{1}$ \\ ${ }^{1}$ Institute for Regional Geology and Palaeontology, Faculty of Mining and Geology, Kamenička 6, 11000 Belgrade, \\ Yugoslavia \\ ${ }^{2}$ Seismological Survey of Serbia, Tašmajdan bb, 11000 Belgrade, Yugoslavia
}

Received: 2 May 2000 - Accepted: 8 March 2002

\begin{abstract}
This paper focuses on the tectonic activity in the area of the Serbian part of the Pannonian Basin (SPPB) and its far southern rim from the end of the Pliocene up to the recent time. The corresponding seismic implications are also discussed. It is shown that the major part of the Pannonian Basin in the territory of Serbia has been subsiding during the Quaternary, while its rim is uplifting. This is an identical situation to that in the whole Pannonian Basin, being a consequence of the deflection of the rheologically weakened Pannonian lithosphere within a compressive region (Horváth and Cloetingh, 1996). Such a pattern has resulted in the generation of low seismicity in the SPPB. In the bordering zone of the SPPB and uplifted morphostructures of the Dinarides and the Carpathians, in the area of flexural transition from a thick crust towards a thinned one, i.e. from a rigid towards a weakened lithosphere, a great number of faults have been activated during the Quaternary. This is marked by the moderate seismic activity of these faults. Strike-slips prevail, but reverse, and rarely gravitational faulting is also present. Finally, the geodynamics of Quaternary deformations is presented. It has been determined that a model of Quaternary tectonic activity in the SPPB and its southern margin depended on: (1) compressive stress, induced in the border zone of the Adriatic plate and Dinaridic orogene, (2) crust thickness and rheological features of the lithosphere as a whole and (3) extension in the Aegean domain.
\end{abstract}

Key words. neotectonics, seismicity, Pannonian Basin, Serbia

\section{Introduction}

The southernmost (south-eastern) part of the Pannonian Basin in the territory of Serbia is marked by a relatively spacious margin of basinal structures, which are genetically related to the Pannonian Basin. On the whole, we are talking about the basinal and peri-basinal area which is of a specific

Correspondence to: M. Marović (nacy@eunet.yu) (“v"-shaped) appearance in plan, and which has penetrated far to the south, along the Morava river, between the Dinaridic and Carpatho-Balkanidic morphostructures (Fig. 1). The Pannonian and particularly Peri-Pannonian regions form a relatively narrow domain located within distinctly compressive surroundings. Such a position has enabled the formation, by the Neogene-Quaternary movements, of an interesting structural content, in many ways different from the rest of the Pannonian Basin (Marović and Djoković, 1989, 1990; Marović et al., 1994, 1996, 1998b).

According to Gutdeutsch and Aric (1988) and Procházkova and Roth (1993), the Pannonian Basin is characterised by weak-to-moderate seismicity, which could not be said about its western and southern rim. The same applies for the area of the Pannonian Basin and its southern rim in the territory of Serbia. The area of the Pannonian Basin in Serbia is characterised by weak seismicity with an irregular distribution of epicentres, which makes it hard to distinguish seismically active faults (the assertion of Horváth, 1984, referring to the whole of the Pannonian Basin). On the other hand, the southern margin of the Pannonian Basin is the most active area of Serbia in the seismic sense, although it is relatively far from the collisional Adriatic-Dinaridic zone which is the major source of the recent compressive stress in these regions. However, the seismicity is of moderate intensity.

Since the seismicity is the consequence of recent tectonic processes, it is particularly important to determine: when such a tectonic regime was established, what its structural content is, and what is the character of stress as responsible for the seismicity. Recently, Horváth and Cloetingh (1996) have shown that major changes in the tectonic regime in the area of the Pannonian Basin and its inner rim occurred at the end of the Pliocene and the beginning of the Quaternary. In other words, the magnitude of intraplate stress increased, which effected the kinematics of the Pannonian basinal and peri-basinal structures. According to them, such a regime continued all the way up to the Holocene and is responsible for the contemporary tectonic movements, and thus for the seismicity. This paper describes the Pliocene-Quaternary 
and Quaternary tectonic activity of the southern part of the Pannonian basin and its rim in the territory of Serbia, as well as its seismic implications.

\section{Pre-quaternary tectonic fabric: a short review}

\subsection{Geotectonic setting}

The Pannonian basinal region and its southern margin in Serbia are located in areas of rather complicated Alpine tectonic fabric. These terrains were, during the Mesozoic, the Palaeogene and the lower part of the Early Miocene, mostly exposed to the major compression of the formational contents. During such a process, three large geotectonic units were formed: Dinarides, Carpatho-Balkanides and SerbianMacedonian Massif (Fig. 1, insert (B)). These units comprise a large number of smaller subunits of different orders, nappes, overthrusts, faults and folding structures: with western and south-western vergences in the Dinarides and eastern vergences in the Carpatho-Balkanides. Such plicative and nappe-and-overthrust fabric is the result of multi-phased Mesozoic-Palaeogene tectonic shortening, occurring during the convergence of several oceanic and continental entities in the Tethyan realm between the African and European plates. By the end of the Late Cretaceous and the beginning of the Palaeogene, all subduction-collisional processes in these terrains were over (Grubić, 1980; Karamata and Krstić, 1996). During the Latest Palaeogene and ending during the lower part of the Early Miocene, the extrusion and incorporation of the Tisza lithospheric entity into the area of the future Pannonian Basin occurred. This event also caused a great deal of bending of the South-Carpathian structural units and the divergence of the structures in the northernmost parts of the Vardar zone (toward West and East) (Ratchbacher et al., 1993; Linzer et al., 1998; Zweigel at al., 1998). Such a preexisting pattern in the territory of Serbia largely influenced the geometry of the Neogene structures of the Pannonian Basin and its rim.

At the beginning of the Early Miocene, the basic fault pattern was also defined. The major position was held by longitudinal faults striking from NW-SE to NNW-SSE and NNE-SSW (in the Dinarides) and NNW-SSE to N-S (NNESSW) in the Carpatho-Balkanides. The other two clearly distinguished fault systems have a transverse and a diagonal character in relation to the strike of the regional tectonic units and plicative structures. Those faults strike NE-SW, $\mathrm{N}-\mathrm{S}$ and E-W (in the Dinarides) and NE-SW, NW-SE and WSW-ENE (in a part of the Vardar Zone and in the CarpathoBalkanides). In that way, major tectonic units obtained a blocky structure, which was of great importance later on in defining the geometry of the Neogene structures of the Pannonian Basin and its southern rim.
2.2 Pre-quaternary basinal and peri-basinal fabric: genesis and evolution

There is general agreement among almost all modern scientists that lithospheric extension played an important role in the formation of the Pannonian Basin, and that this basin comprises the areas with a thin continental crust and a high lithospheric heat flow (Stegena et al., 1975; Sclater et al., 1980; Horváth and Royden, 1981; Royden et al., 1982, 1983; Horváth and Rumpler, 1984; Royden, 1988; Bergerat, 1988; Horváth, 1990, Csontos et al., 1991, 1992; Tari et al., 1992; Horváth, 1993; Csontos, 1995; etc.). In other words, it is defined as a back-arc basin which originated during the process of subduction and collision of the European lithosphere below continental fragments of the Inner Carpathians. The individualised basins and the troughs within the Pannonian Basin are connected to the local crustal extensions, i.e. to the transtensional activity of the faults striking NE-SW and WNW-ESE, as well as to tensional processes and normal faulting. The majority of authors are also of the opinion that the subsidence within the Pannonian Basin went through two phases. During the first phase, starting from the Ottnanghian and continuing through the Karpatian and the Badenian (rift phase), subsidence was mostly the result of the crustal (and lithospheric) extension and occurred within the strictly faultdefined areas. The second phase that started in the upper part of the Middle Miocene and continued into the Pliocene (postrift phase) is characterised by slower subsidence induced by the lowering of the thermal anomalies (Horváth and Royden, 1981). The SPPB and its direct southern rim originated from and developed according to a similar scenario. We should keep in mind that in these regions, especially in the marginal parts of the basin, extensional processes and thermal activity were less distinguished and increasingly weaker and weaker southwards.

The beginning of extension in the SPPB and its southern rim is also connected to the Ottnanghian and the Karpatian (Marović et al., 1998b). Numerous basins, filled with freshwater deposits, mostly clastic, with a thickness of more than $1500 \mathrm{~m}$ in places, were formed in this area at that time. The geometry of the basinal structures is controlled by the preexisting fault pattern, the major role in subsidence belonging to the transverse and diagonal faults (in relation to the strike of the regional structures), and the subordinate role to the longitudinal ones.

The paroxysm of the extensional processes that was distinguished during the Badenian in the Pannonian Basin had an effect on its southern part and its rim on the territory of Serbia. It was marked by the further subsidence of the SPPB and its southern rim. Due to such activity, a marine ingression took place towards the region south of the Sava and, in particular, south of the Danube. However, some of the Ottnanghian-Karpatian basins within the southern surroundings of the Pannonian Basin in the territory of Serbia, did not experience subsidence during the Badenian. Those basins were inverted even before the Badenian and since that time, continuing into the Recent, they have been subjected 


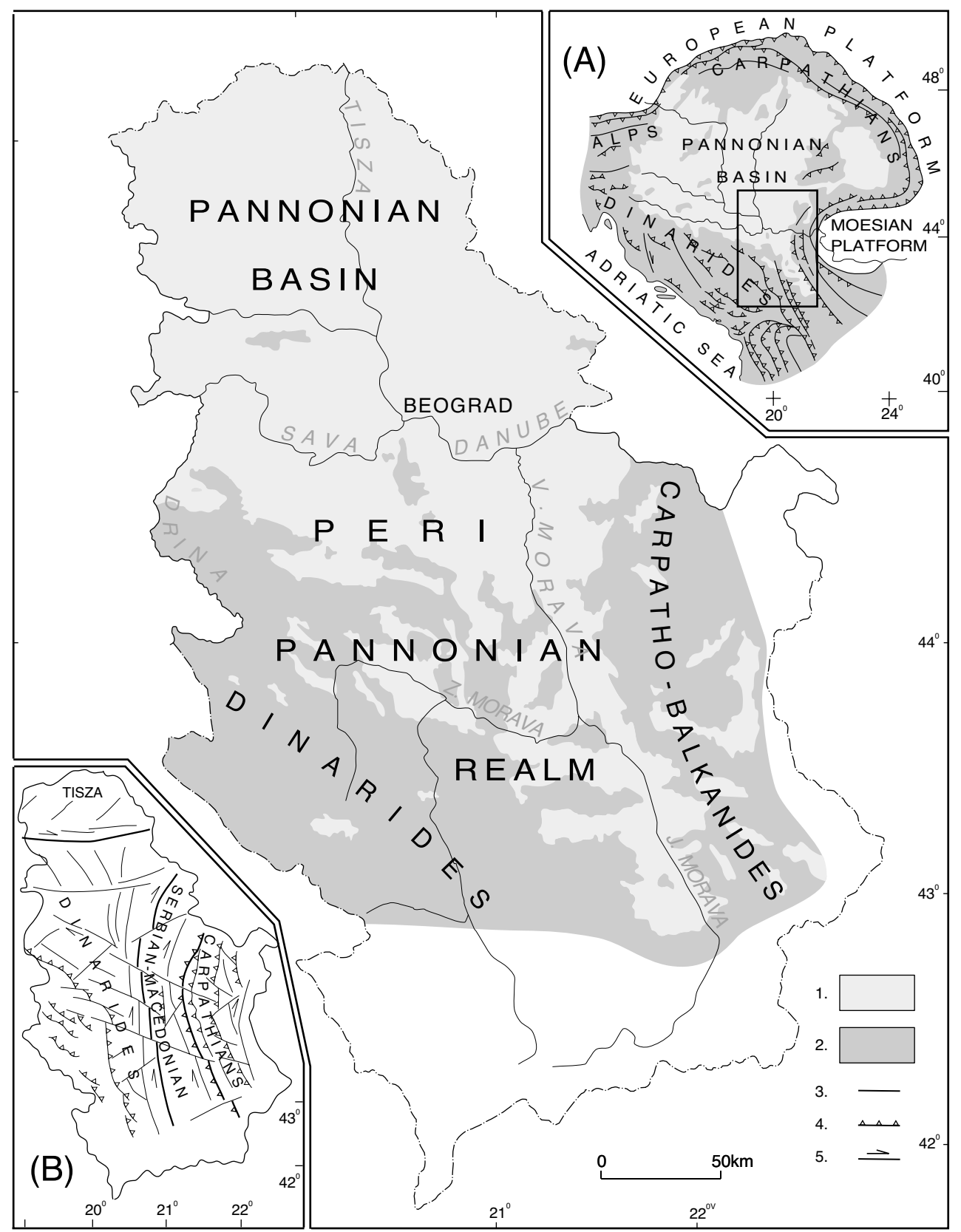

Fig. 1. Serbian part of the Pannonian Basin and its southern margin: 1. Neogene and Quaternary deposits; 2. Pre-Neogene deponates of the mountain systems of the Dinarides and Carpatho-Balkanides; 3. major fault; 4. major overthrust; 5. major strike-slip fault; Insert: (A) position of the research area within the European Alpides and (B) major tectonic units of the basement of the Serbian part of the Pannonian Basin and its wider surroundings.

to uplifting and have been gradually included in the uplifted morphostructural rows of the Dinarides and the CarpathoBalkanides. The inversion is indicated by the lack of deposits younger than the Karpatian in these terrains (Marović et al., 1998b). The inversion is connected to the domination of the distinctly compressive regime (between the Adriatic and Moesian plates) over the extensional processes within these areas.

However, the basinal regions in the SPPB which had not been inverted, were subjected to post-rift subsidence (ther- mal stadium, Horváth, 1993) during the late Middle Miocene and the Late Miocene (and Miocene-Pliocene), as was the whole basin. During that time, the Pannonian Basin was exposed to slow but more general subsidence than in the Badenian. This is indicated by the transgressive position of the Sarmatian, Pannonian and even Pontian deposits over the Pre-Badenian ones (Marović et al., 1995). On the other side, we have, on the southern margin of the Pannonian Basin (the Neogene Velika Morava Trough), the successive inversion of basinal regions, going from the South to the North, to- 


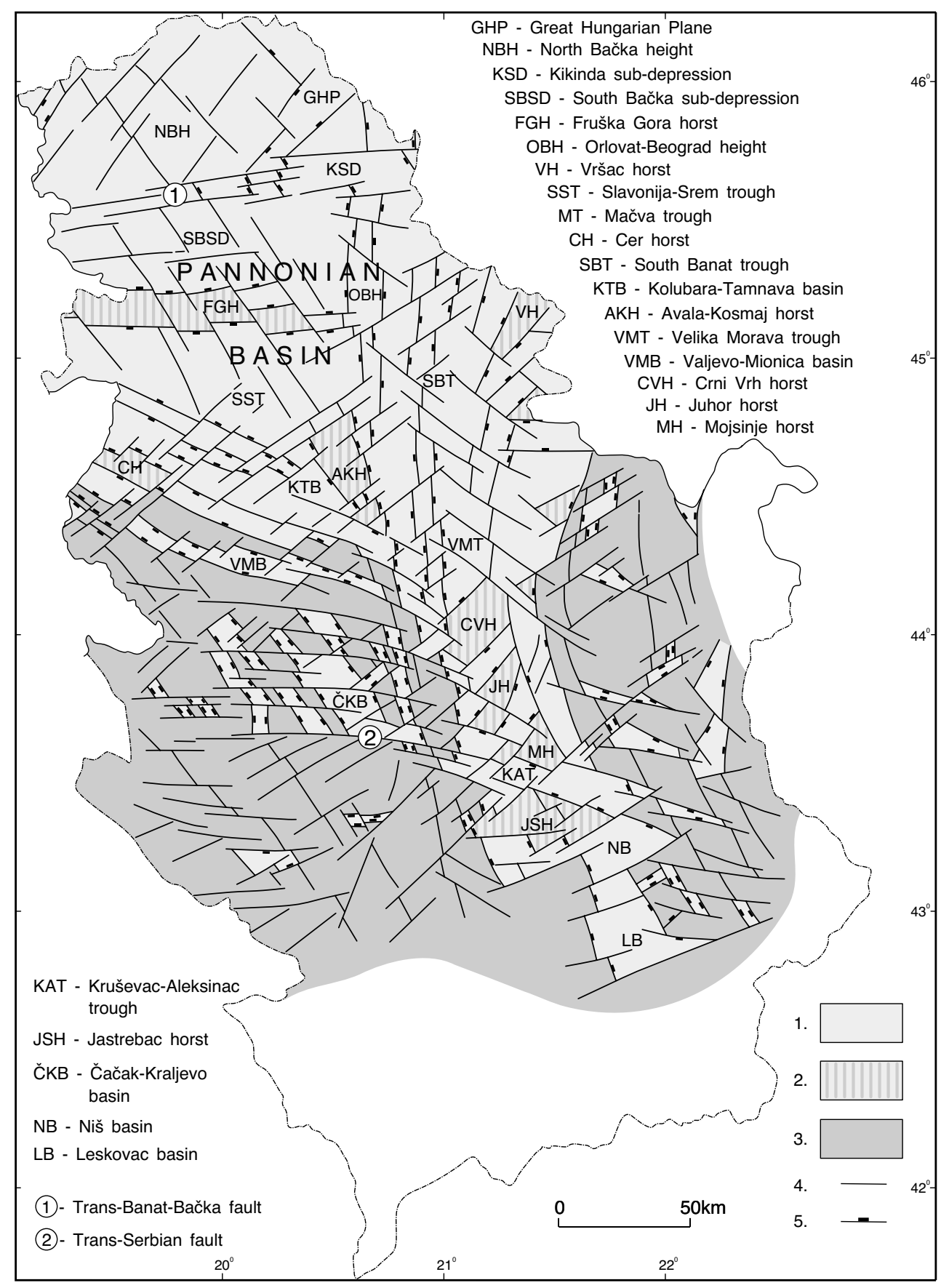

Fig. 2. The Neogene fault fabric and blocky structure of the Serbian part of the Pannonian Basin and its southern rim: 1. basinal structures; 2. horst structures within basinal regions; 3. uplifted morphostructures of the Dinarides and Carpatho-Balkanides; 4. major fault; 5. downthrown block.

ward the interior parts of the Pannonian Basin (Marović et al., 1995), from the end of the Badenian into the Pliocene and Quaternary. Distribution of the Neogene deposits and regression tendency in the South - North direction, point to such an activity. The already inverted basins in the broader surroundings of the Pannonian Basin that had been filled mostly with clastics - the freshwater equivalents of the OttnanghianKarpatian age, were exposed to moderate-to-strong uplifting from the Sarmatian all the way into the recent.
The final result of such tectonic activity was the basic Neogene structural pattern (Fig. 2), as well as the relative thinning of the crust within the SPPB and its thickening in the Dinarides and Carpatho-Balkanides (Fig. 3). Such a pattern (the Neogene fault pattern, the configuration and rheologic characteristics of the crust and the lithosphere as a whole) is going to be one of the major controllers of the tectonic activity during the Plio-Quaternary and Quaternary. 


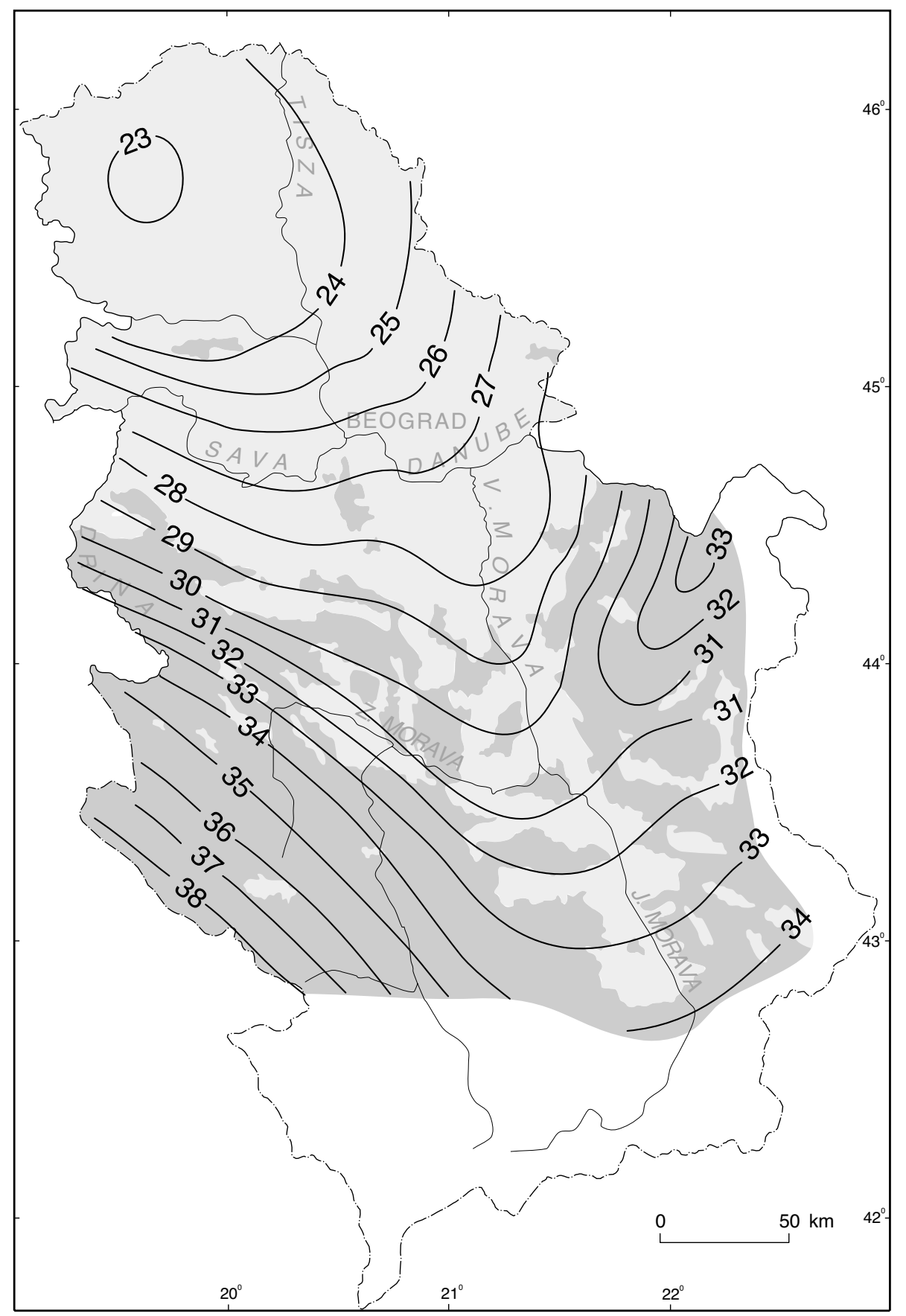

Fig. 3. Crustal thickness map of the Serbian part of the Pannonian Basin and its southern rim (produced on the basis of the compiled data from Glavatović 1989, Starčević 1995, and Starčević and Djordjević 1997). Thickness is given in km.

\section{Sources for the information, data quality level and methodology}

To determine the Quaternary tectonic activity in the SPPB and its southern rim, various data, relevant for understanding this issue, were used. The sources for the information were, for the most part, geological, geomorphological, geophysical and other data of different quality and varying levels of reliability. Some of them, especially the seismic data is rather old and should be regarded with certain caution. Unfortunately, numerous data on the structure of the Pannonian Basin in the territory of Serbia was not accessible to the authors due to the policy of the institution which holds it. It should also be emphasised that many contemporary research methods that would improve the knowledge of the lithosphere structure or the reconstruction of the latest stress (in situ stress measurement, borehole break-out studies), have not been used at all in the territory of Serbia. These reasons have forced the au- 
thors to refer to the data from and results of research conducted in the Pannonian basin outside the territory of Serbia: either as direct guidelines, or as basic solutions for some of the problems which apply to the SPPB and its southern rim. All of this has limited the possibilities of this paper, which can be regarded as a regional review, proposing a model that has yet to be worked out in more detail.

The Quaternary tectonic activity has mostly been registered on the basis of the Quaternary deposits characteristics (thickness in the first place) and seismicity. Geodetic data has also been taken into consideration. For the reconstruction of the recent stress field and tectonic regime, the following data were also used and consulted: Bergerat et al., 1984; Horváth, 1984; Anderson and Jackson, 1987; Philip, 1987; Gutdeutsch and Aric, 1988; Müller et al, 1992; Rebaï et al., 1992; Zoback, 1992; Becker, 1993; Gerner et al., 1995; Peresson and Decker, 1996; Bada et al., 1998; Bada, 1999; Gerner et al., 1999.

\subsection{MOHO depth}

The Quaternary tectonic activity of the SPPB and its southern rim has taken place in the area of blocky structure where the continental crust is of unequal thickness. Such a preexisting pattern had a great influence on the Quaternary deformations.

The data on the crust thickness (Fig. 3) are derived from three sources. For the major part of the Peri-Pannonian region, i.e. the area south from the Sava and Danube rivers, the data presented by Glavatović (1989) is used. The MOHO position was determined by the inversion of the regional Bouguer anomaly component using the QR-algorithm and spline-interpolation (Glavatović, 1988). For the SPPB and the western part of the southern Carpathians in Serbia, where crust thickness data was not obtained by such calculations, the data by Starčević (1995) and Starčević and Djordjević (1997) obtained on the basis of the empirical relations between the regional Bouguer anomaly values and the crust thickness using the method by Demenitskaya (1967) was used. The crust thickness map (Fig. 3) was produced by a compilation of this data, with certain minor simplifications that, considering the scale, have not significantly influenced the final result. The data on the general properties of the lithosphere (thickness, rheology and heath flow) presented in the papers by Praus et al., (1999), Horváth, (1993) and Horváth and Cloetingh, (1996) was also used.

\subsection{The Neogene structural pattern}

The blocky structure of the SPPB and its southern rim, formed during the Miocene and Pliocene rift and post-rift subsidential stadium, is shown on the basis of the data by Marović et al., (1998b) and additional research (Fig. 2).

\subsection{Thicknesses of the Plio-Quaternary deposits}

Owing to the fact that the SPPB is covered with numerous boreholes that were drilled during oil research and exploitation as well as for some other purposes (hydrogeology, pro- ducing the Basic Geological Map of the SFRY, 1:100 000, etc.), the Quaternary deposits in this area have been very well studied. According to the data from the boreholes, certain lithotypes and their thicknesses were identified. Preloess polycyclic fluviolacustrine (and marshy) and deluvialproluvial deposits whose thickness is presented in Fig. 4 were of particular importance for the determination of Quaternary vertical tectonic mobility. The quality of the obtained data is of a relatively high level, especially for the region of north Bačka and eastern Banat where most of the boreholes are located. The data quality is worse for the rest of the SPPB, particularly for its southern margin.

\subsection{Recent vertical tectonic activity}

Recent vertical tectonic activity was confirmed by geodetic leveling surveys, so the results shown on the Map of the Recent Vertical Displacements of Earth's Crust in Yugoslavia 1: 2500000 (Federal Geodesy Survey, 1972) were almost completely accepted. As the map (Fig. 5) represents a construction based on a relatively small amount of rather old data it should be treated with certain caution. The fact that the map is the result of considerable generalization and extrapolation it has a review character and it can be used only for regional review purposes.

\subsection{Seismic data}

The realisation that a tectonic regime reigning today in the Pannonian Basin and its wider rim was established at the end of the Pliocene and the beginning of the Quaternary (Horváth and Cloetingh, 1996) helped to determine the morphology and kinematics of the faults active during the Quaternary, on the basis of seismicity. For that purpose, the location and spatial distribution of epicentres, the depths of focuses, released energy and focal mechanisms of faulting, were analysed. Besides this, other information was taken into consideration: geological, geomorphological and that acquired by remote sensing.

Seismicity, as the most relevant parameter for the detection of contemporary fault activity in the Pannonian and PeriPannonian region in Serbia, is the source of data of various levels of reliability (Fig. 6.). Very unreliable are data related to events before 1900 (stronger earthquakes: Fruška Gora, Veliko Gradište, Svilajnac, Peć and Prizren were estimated I = 9). During the period 1900-1970, the macroseismic location of epicentres was performed (stronger earthquakes: Rudnik, Lazarevac, Juhor, Krupanj, Svetozarevo, Vranje, Vitina were determined as I = 8-9). From 1970 until the present, instrumental recording and evaluation of earthquake magnitude has been performed. During this period, only three moderate-magnitude earthquakes with $\mathrm{M}=5.2-$ 5.6 (Kopaonik, Mionica and Trstenik) have occurred (Table 1). There is a justified suspicion that earthquakes registered before 1970 were also not much stronger; in any case they were equal to or less than $M=6$. Most focuses were in the range of 5 to $10 \mathrm{~km}$ deep, rarely deeper $(15-20 \mathrm{~km})$, 


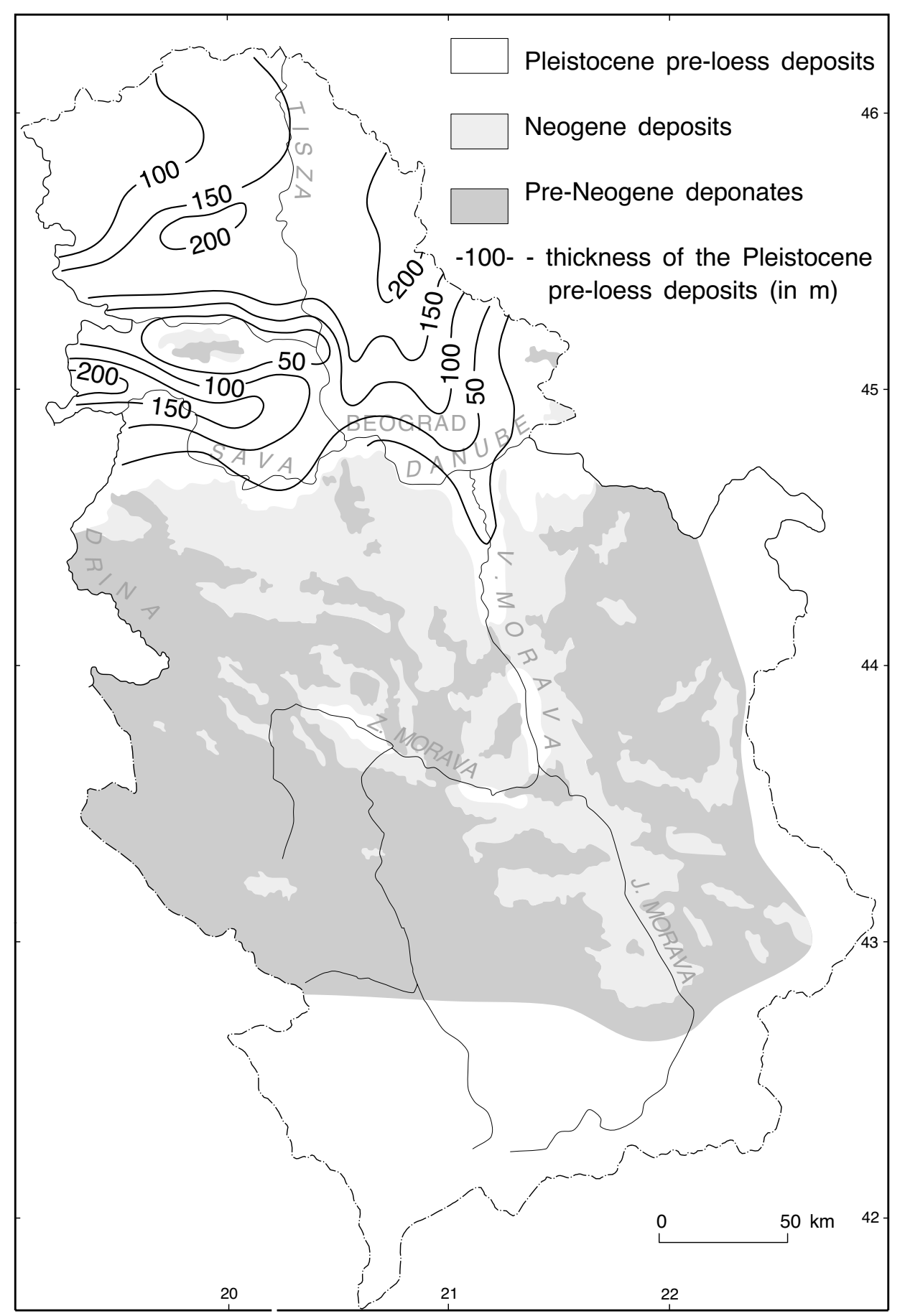

Fig. 4. The map of the thickness of the Pleistocene-pre-loess deponates in the Serbian part of the Pannonian Basin and its southern rim.

and therefore all in the upper crust (depths have been distinguished instrumentally for newer events, at the local stations with short distances).

The kinematics of contemporary faulting was established on the basis of earthquake focal mechanisms (Fig. 7). The mechanism parameters (Table 1) were determined using the data on the polarity of P-wave first arrivals by applying the double-couple model. The wave emergence angles were calculated on the basis of the seismic velocity model con- structed for the Serbian area (Radovanović, 1995). The plot of the fault plane solutions and stress axes of earthquakes is done by the RAKE computer program (Louvari and Kiratzi, 1997). Unfortunately, a relatively small number of earthquakes were analysed, not often being representative and mostly coming from the central part of Serbia.

The kinematics of other seismically active faults was established by analogy with the faults with the same geometric characteristics for which the focal mechanism solutions 
Table 1. Parameters of the 18 seismic events, used for fault plane solution

\begin{tabular}{|c|c|c|c|c|c|c|c|c|c|c|c|c|c|c|c|c|c|}
\hline \multirow[b]{2}{*}{ No } & \multirow[b]{2}{*}{ Date } & \multirow[b]{2}{*}{ Time } & \multirow[b]{2}{*}{ Lat(N) } & \multirow[b]{2}{*}{ Lon(E) } & \multirow[b]{2}{*}{ Depth } & \multirow[b]{2}{*}{ Mag } & \multirow[b]{2}{*}{$A z$} & \multicolumn{2}{|c|}{ Plane 1} & \multicolumn{4}{|c|}{ Plane 2} & \multicolumn{2}{|l|}{$\mathrm{P}$} & \multicolumn{2}{|l|}{$\mathrm{T}$} \\
\hline & & & & & & & & Dip & Rake & $A z$ & Dip & Rake & $A z$ & Dip & $A z$ & Dip & Author \\
\hline 1 & $72 / 01 / 10$ & $04: 32$ & 43.53 & 21.54 & 20.00 & 4.40 & 203 & 52 & 172 & 298 & 84 & 38 & 64 & 21 & 168 & 31 & SR \\
\hline 2 & $78 / 13 / 04$ & $18: 05$ & 43.31 & 21.04 & 7.00 & 5.00 & 224 & 45 & 143 & 342 & 65 & 51 & 99 & 12 & 205 & 53 & SR \\
\hline 3 & $80 / 18 / 05$ & $20: 02$ & 43.29 & 20.94 & 5.00 & 5.60 & 213 & 89 & 161 & 304 & 71 & 1 & 260 & 13 & 167 & 14 & SR \\
\hline 4 & $83 / 10 / 09$ & $06: 14$ & 43.26 & 20.94 & 12.00 & 5.00 & 19 & 89 & -149 & 289 & 59 & -1 & 248 & 22 & 150 & 21 & SR \\
\hline 5 & $84 / 07 / 09$ & $00: 44$ & 43.29 & 21.04 & 9.00 & 4.40 & 235 & 48 & -97 & 65 & 42 & -83 & 91 & 84 & 330 & 3 & SR \\
\hline 6 & $85 / 18 / 05$ & $01: 14$ & 43.31 & 20.99 & 12.00 & 4.40 & 55 & 55 & 152 & 162 & 68 & 38 & 286 & 8 & 23 & 42 & SR \\
\hline 7 & $87 / 14 / 08$ & $06: 24$ & 43.72 & 20.50 & 17.00 & 4.40 & 55 & 63 & 6 & 322 & 85 & 153 & 12 & 15 & 275 & 23 & SR \\
\hline 8 & $87 / 19 / 04$ & 03:55 & 43.68 & 20.52 & 19.00 & 4.40 & 6 & 49 & 63 & 224 & 48 & 118 & 115 & 1 & 206 & 70 & SR \\
\hline 9 & $88 / 27 / 05$ & $14: 18$ & 44.16 & 21.59 & 7.00 & 4.40 & 10 & 49 & 45 & 247 & 58 & 129 & 310 & 5 & 212 & 57 & SR \\
\hline 10 & $90 / 08 / 10$ & $23: 42$ & 44.04 & 19.38 & 4.00 & 4.00 & 79 & 51 & 53 & 309 & 52 & 127 & 14 & 1 & 283 & 62 & SR \\
\hline 11 & $91 / 28 / 10$ & 00:02 & 44.27 & 21.49 & 4.00 & 4.40 & 57 & 68 & -53 & 174 & 42 & -146 & 11 & 52 & 121 & 15 & SR \\
\hline 12 & $91 / 29 / 04$ & $21: 38$ & 44.11 & 19.07 & 8.00 & 4.40 & 4 & 55 & 131 & 127 & 52 & 47 & 66 & 2 & 333 & 57 & SR \\
\hline 13 & $94 / 16 / 12$ & $05: 45$ & 44.07 & 21.31 & 13.00 & 3.90 & 18 & 56 & -148 & 269 & 64 & -38 & 230 & 45 & 325 & 5 & SR \\
\hline 14 & $98 / 29 / 09$ & $22: 15$ & 44.22 & 20.08 & 18.00 & 5.50 & 102 & 53 & 56 & 330 & 48 & 126 & 215 & 3 & 311 & 64 & SR \\
\hline 15 & $99 / 07 / 01$ & $07: 41$ & 43.70 & 21.09 & 19.00 & 5.00 & 209 & 50 & -58 & 345 & 50 & -122 & 187 & 66 & 277 & 0 & SR \\
\hline 16 & $99 / 30 / 04$ & 03:30 & 44.20 & 20.08 & 18.00 & 5.20 & 272 & 73 & 159 & 176 & 70 & 162 & 44 & 2 & 135 & 27 & SR \\
\hline 17 & $97 / 11 / 13$ & $00: 49$ & 43.28 & 20.42 & 16.00 & 4.40 & 142 & 57 & 33 & 33 & 63 & 142 & 89 & 4 & 355 & 45 & SR \\
\hline 18 & $85 / 01 / 05$ & 13:06 & 42.58 & 22.13 & 19.00 & 4.40 & 329 & 73 & -142 & 227 & 54 & -21 & 194 & 38 & 94 & 12 & SR \\
\hline
\end{tabular}

had already been determined, as well as by their position within the stress fields of compressive and tensile affinity, presented for the Pannonian Basin and its wider surroundings by Gerner et al. (1999) and Bada (1999).

\section{Deposit character and vertical tectonic mobility}

During the Quaternary, a relatively thick succession of genetically different types of deposits has been deposited in the area, and significantly less on its rim. Pre-loess polycyclic fluviolacustrine (and marshy) and deluvial-proluvial deposits (Fig. 4) are widespread, have great thickness and are of particular importance. The pre-loess polycyclic fluviolacustrine deposits, in some places over $200 \mathrm{~m}$ thick, show intense subsidence over a wide region of the SPPB during the Pleistocene. The subsidence was, however, less intense compared to that expressed in the central parts of the Pannonian Basin - in the region of the Great Hungarian Plane, where subsidence was much more intense, according to the thickness (more than $700 \mathrm{~m}$ ) of the Quaternary sediments (R onai, 1974). Deluvial-proluvial sediments ("Srem series", "Kličevac series", etc.) were formed on the slopes of Fruška Gora and on the rim of the Pannonian Basin, especially on its eastern part, toward the Carpathians (Rakić, 1977). The relation between the fluviolacustrine (and marshy) and the deluvial-proluvial deposits still remains unclear. In particular, it is not clear whether these are synchronous deposits or whether the deluvial-proluvial deposits are younger. In any case, the fluviolacustrine (and marshy) deposits point to subsidence, and the deluvial-proluvial deposits point to transitional regions toward uplifted areas.

The Plio-Pleistocene subsidence and the deposition of fluviolacustrine (and marshy) deposits spread also over some of the basinal areas of the southern rim of the Pannonian Basin that were inverted even at the end of the Pontian; for example, the northern part of the Velika Morava Trough, where the major part of the contemporary course of the Velika Morava is located (Fig. 8). This fact shows the intensifying of subsidence within the SPPB and its innermost rim during the Pleistocene. However, the major part of the area, composed of these deposits on the rim of the SPPB was inverted at the end of the Lower Pleistocene and transformed into the uppermost Quaternary terrace.

In the upper part of the Pleistocene, large areas of the SPPB and its inner southern rim were covered with loess and loessoïde deposits.

In the Holocene, vertical tectonic activity occurred according to an almost identical scenario as in the Pleistocene. Areas of subsidence are marked by fluvial, marshy and swampy deposits. Mainly deluvial, rarely deluvial-proluvial deposits, were formed on the transitional areas towards uplifted structures.

The regions outside of the SPPB, i.e. its distant southern margin, especially axial parts of the Dinarides and CarpathoBalkanides, have been exposed to uplifting during the Quaternary. Such activity has been followed by strong erosion 


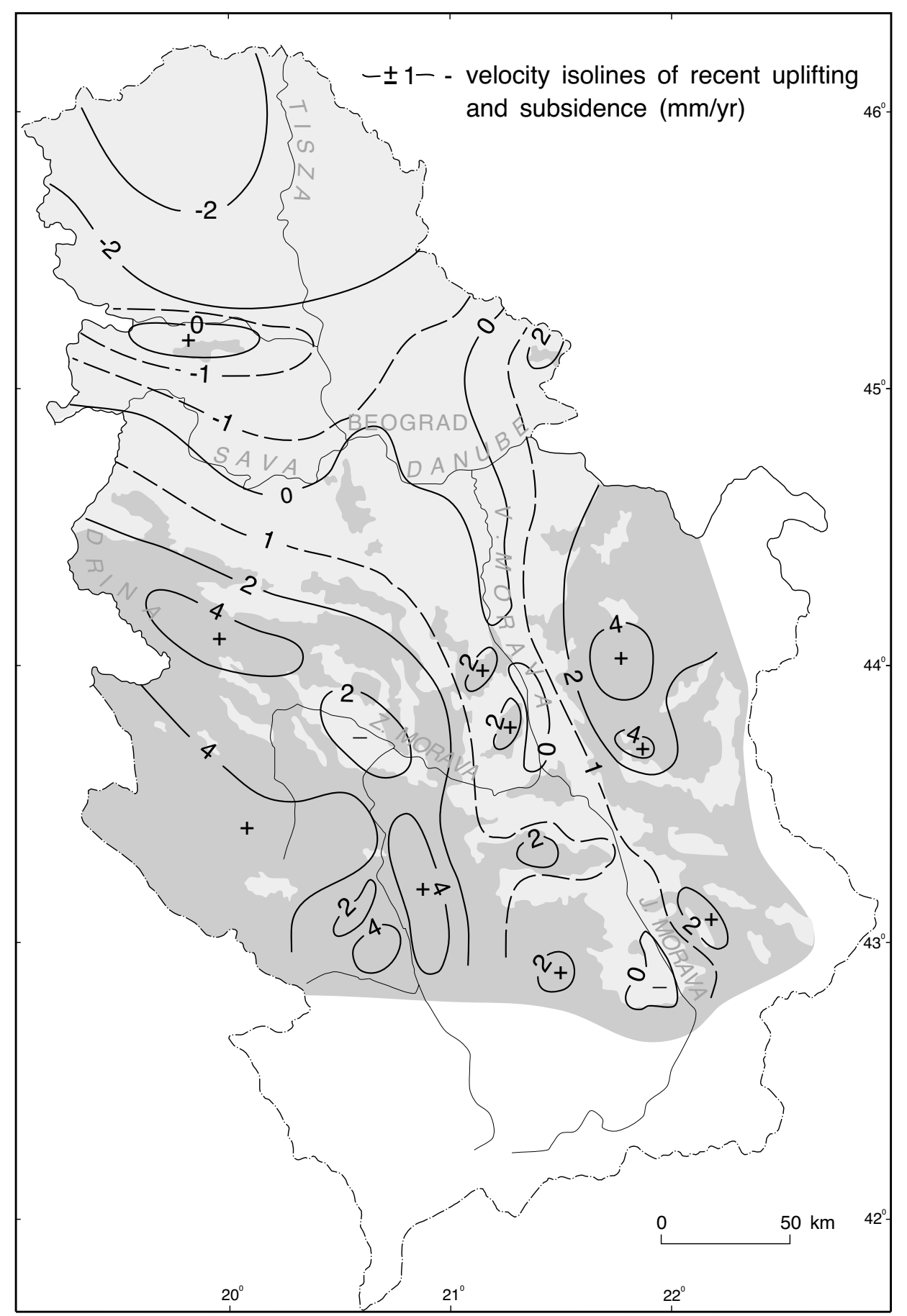

Fig. 5. Velocity map of the recent vertical tectonic movements within the Serbian part of the Pannonian Basin and its wider surroundings (modified after Federal Geodesy Survey, 1972).

and deposition of various continental deposits, genetically related to such a tectonic regime.

Such a picture of distribution of uplifted and subsided areas, detected on the basis of the stratigraphical-facial characteristics of the Quaternary deposits, is largely confirmed by traditional geodetic leveling surveys (Fig. 5). It is evident that the SPPB has been mostly subsiding in the recent time at a rate of $0-2 \mathrm{~mm} / \mathrm{yr}$. This cannot be said for the hilly
Fruška Gora region and the basin rim, especially the eastern part toward the Carpathians. These regions have recently been uplifting at a velocity of $0-1 \mathrm{~mm} / \mathrm{yr}$. In the wider rim of the SPPB, in the area of the Dinarides and the CarpathoBalkanides, the uplifting rate has increased up to $2-4 \mathrm{~mm} / \mathrm{yr}$. 


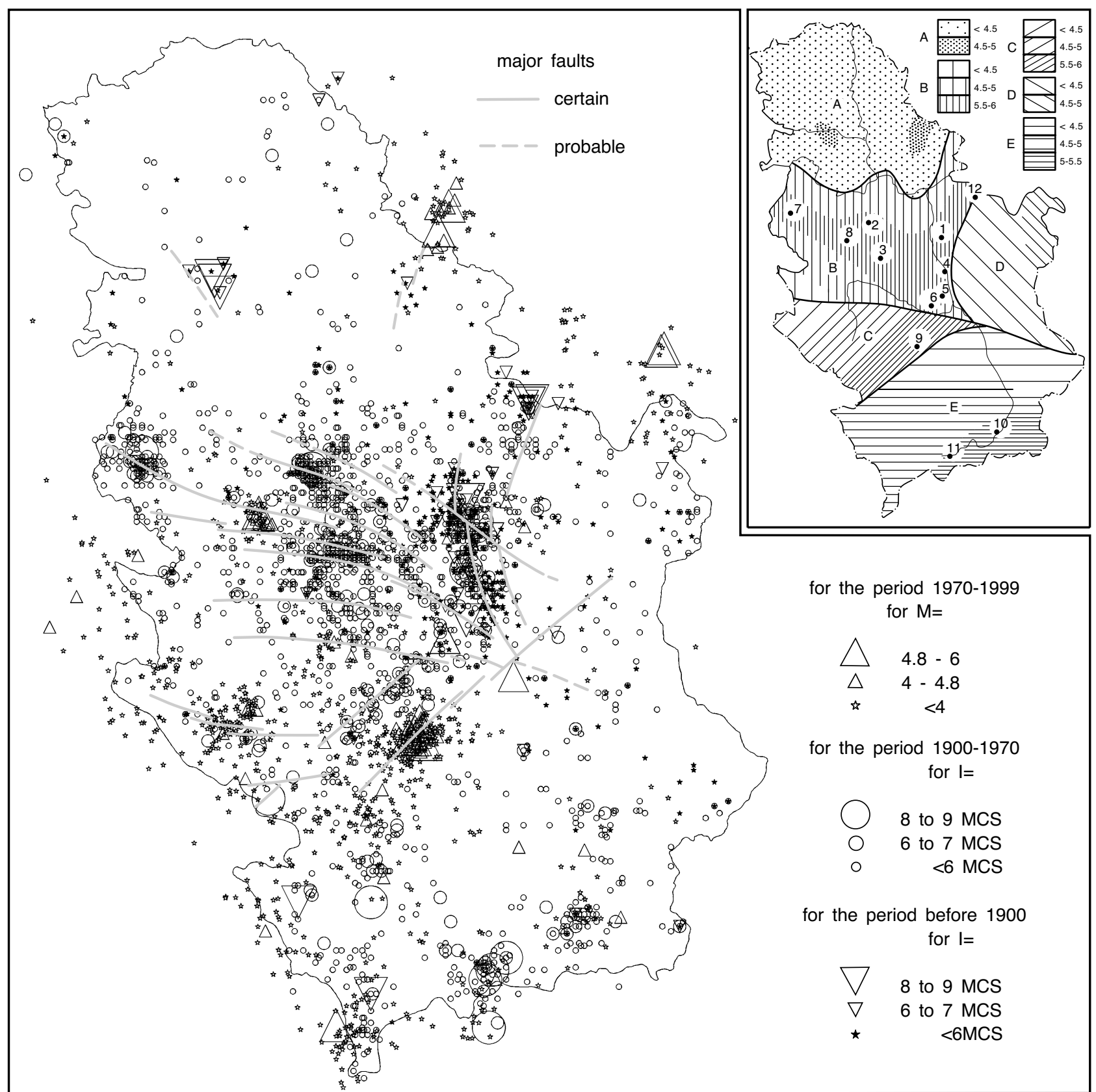

Fig. 6. Seismicity of the territory of Serbia and major active faults. Insert: Major seismic zones in Serbia, with marked maximum expected magnitudes: (A) The Pannonian basin (B) Peri-Pannonian margin (C) SW Serbia (D) Eastern Serbia and (E) Southern Serbia, and location of the strongest earthquakes: (1) Svilajnac, (2) Lazarevac, (3) Rudnik, (4) Svetozarevo, (5) Juhor, (6) Trstenik, (7) Krupanj, (8) Mionica, (9) Kopaonik, (10) Vranje, (11) Vitina, (12) Golubac. Fruška Gora and Pec events are excluded because of the unreliability of data.

\section{Fault fabric and seismicity}

\subsection{Seismicity}

The seismicity, as the best indicator of the contemporary fault activity and Quaternary fault activity as a whole, has been unequal in the SPPB and its southern rim. It has been basically weak to moderate, and it marks the activity of faults with different kinematic features.

The SPPB shows low seismicity (Fig. 6). These are re- gions where magnitudes do not exceed $\mathrm{M}=4.5$. The exceptions, with a possible generation of earthquakes up to $\mathrm{M}=$ 4.5-5, are Fruška Gora (i.e. the event from 1739-1741 which should be accepted with a certain reserve) and the region of eastern Banat, which belongs to the Timisoara epicentral zone. The distribution of earthquakes, except for Fruška Gora and eastern Banat, shows low linearity so it is quite difficult to locate seismically active faults. The epicentres of weak earthquakes are mostly scattered. 


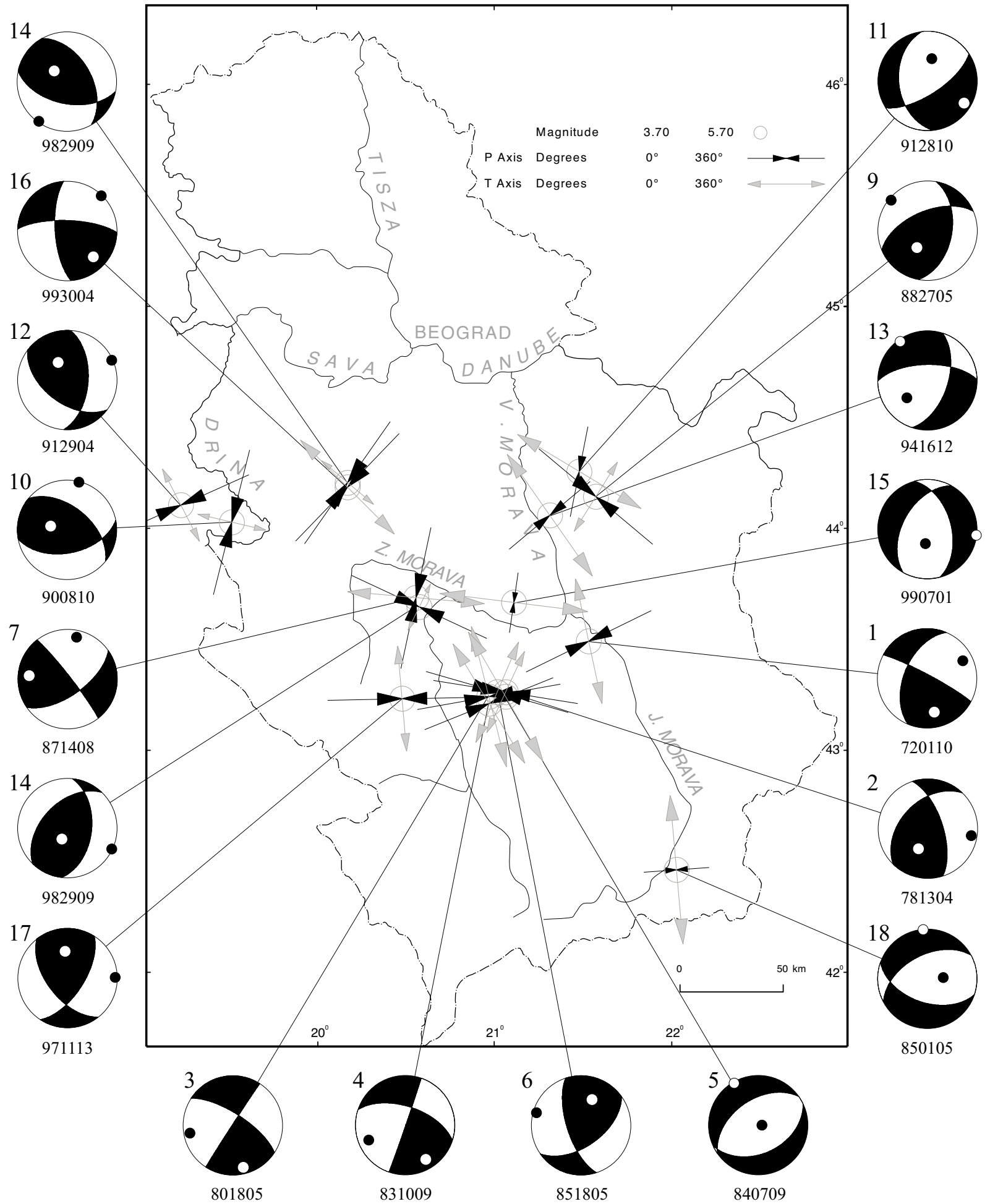

Fig. 7. Fault plane solution for some of the earthquakes in the territory of Serbia. Horizontal projection of $\mathrm{P}$ (grey) and $\mathrm{T}$ (black) axes.

The inner southern margin of the SPPB belongs to the seismically most active regions in Serbia. It is a wide epicentre concentration zone, approximately " $v$ "-shaped, covering western and central parts of Serbia and surrounding the Pannonian Basin from the South (Fig. 6, insert). Earthquakes with maximum magnitude $M=5.5-6$ can be expected in this region. Actually, this is the area where several strong earthquakes of $\mathrm{I}=8-9$, and recent events with $\mathrm{M}=5.2-5.5 \mathrm{oc}-$ curred. It is interesting to note that these strongest earthquakes have occurred only once, without repetition in the same locality (according to the data provided for the last 100 years). New earthquakes occurred at places where there was 


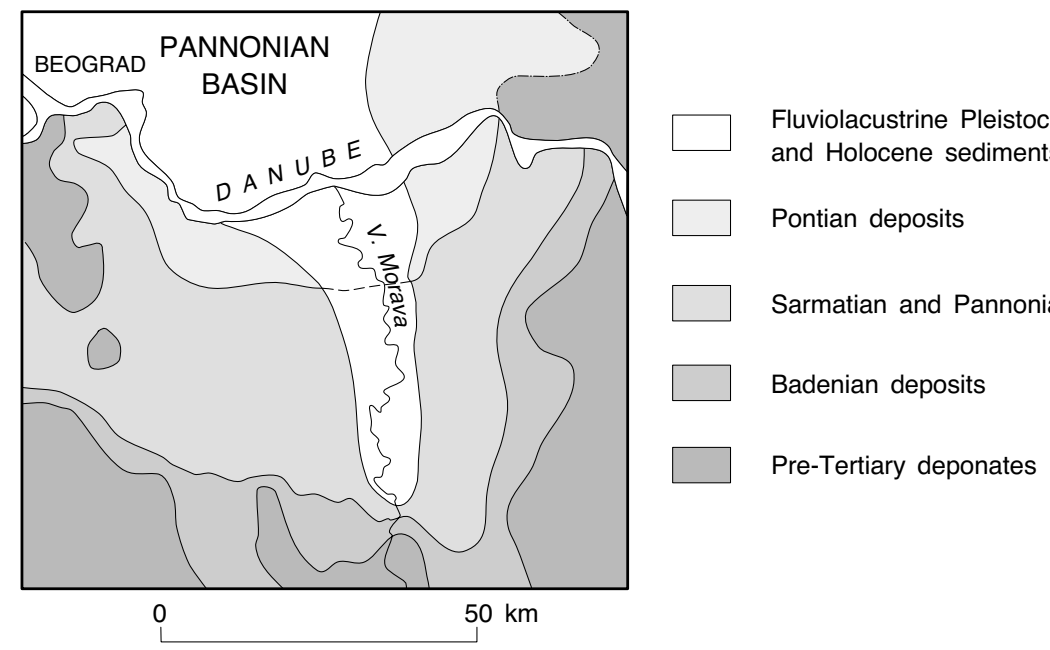

Fig. 8. Simplified geological map of the northern part of the Neogene Velika Morava Trough (based on The Geologic Map of SFRY 1:500 000).

no stronger seismic activity before. It shows that the whole zone is a generator of seismicity, where not only the preexisting significantly seismoactive faults are activated, but also fault structures that did not have significant seismic activity before.

The distant margin of the SPPB is of unequal seismic activity. In the region of SW Serbia, in the area of Kopaonik Mt., maximum magnitudes of $\mathrm{M}=5.5-6$ can also be expected (Fig. 6, insert). Going north-westwards away from Kopaonik, seismic activity decreases down to $M<4.5$. On the other hand, the major part of eastern Serbia (the region of the Carpatho-Balkanides) and northern part of SE Serbia have low seismic activity. Mostly irregularly distributed and rare epicentres prevent a clear marking of seismically active faults.

\subsection{Kinematics of the contemporary faulting}

As far as the kinematics of the contemporary faulting is concerned, it is evident that strike-slips prevail, but normal and reverse faulting is also present. Thus, we can say that within the inner southern margin of the SPPB, a compressive regime of the strike-slip type prevails, with a horizontal axis of maximum compressive stress oriented SW-NE and with a tendency to bend eastward (Fig. 7). This mostly fits into a general plan of the maximum horizontal stress direction, given for the PANCARDI region by Gerner et al. (1999), and Bada (1999). Within the distant southern margin of the SPPB, tension prevails (a consequence of the Aegean collapse) where the horizontal projection of maximum tensile stress axis is oriented NNW-SSE (Papazachos and Kiratzi, 1996). The boundary between these two stress fields has not been well determined.

By uniting all the relevant facts (seismological, geological and others), the geometry and kinematics of presently active faults have been reconstructed (Fig. 9). It shows that these were mostly faults that were formed before the Quaternary (compare Figs. 2 and 9), in numerous cases even before the Neogene, but their kinematic features were changed or restored according to stress changes.

In the SPPB and its southern rim presently active faults have been reconstructed. Faults striking NNE-SSW with expected right strike-slips, are marked with the epicentres in the eastern part of the basin. On the nearest part of the southern margin of the SPPB, currently active faults can be divided into several systems according to their strike. Systems of faults striking ESE-WNW and NE-SW are predominant. Left strike-slips develop along the faults that belong to the first system, and right strike-slips develop along the faults belonging to the second. All stronger earthquakes in this area have mostly occurred within the segments of the first system. Reverse movements develop along the faults striking NNWSSE (with bending in plan towards NNE- SSW) in the eastern part of this zone, and NW-SE in the western part. Such reverse activity is particularly expressed in the first fault system, but with a gradual transition to right strike-slips going northwards.

Going south-westwards from the nearest part of the margin of the SPPB, faults striking NE-SW, E-W and NW-SE show contemporary tectonic activity. The first two systems comprise a conjugated set with right (NE-SW) and left (E-W) strike-slips, whereas right strike-slips are dominant and many earthquakes, the Kopaonik earthquake with $\mathrm{M}=5.6$ among others, are related to them (Djoković et al., 1995). Considering the orientation of the maximum horizontal stress, we can expect some of the old SW-vergent reverse fault systems striking NW-SE in this area to be reactivated with the same kinematic features, but with lower intensity of movement, in the recent time.

Normal fracturing is characteristic of the southernmost part of the Peri-Pannonian region in Serbia (south from the Scutari-Peć transverse, Fig. 7, event 18). That area might represent the northern boundary of the Aegean extensional 


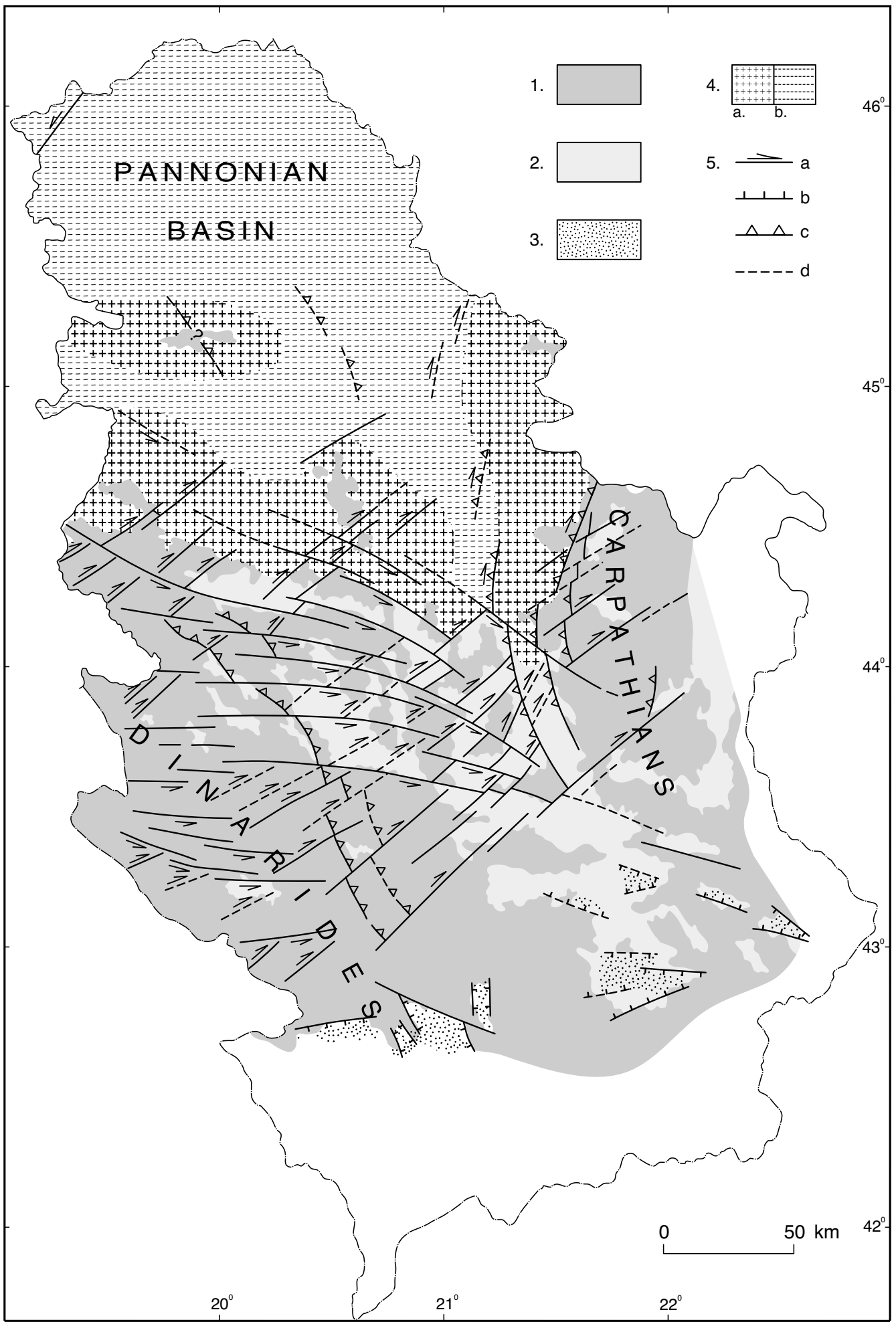

Fig. 9. Quaternary vertical tectonic mobility and seismically active faults in the Serbian part of the Pannonian Basin and its wider rim, Key: 1. Mountain ranges of the Dinarides and Carpatho-Balkanides with an uplifting tendency during the late Neogene and in the Quaternary, 2. Intramontane Neogene basins inverted during the Middle and Upper Miocene with an uplifting tendency in the Pliocene and Quaternary, 3. Areas of the Pliocene and Quaternary subsidence caused by the influence of the Aegean extensional collapse, 4. Quaternary uplifting and subsidence caused by the deflection of rheologically weakened and thinned lithosphere (Horváth and Cloething, 1996) in the Serbian part of the Pannonian Basin and its inner rim: (a) uplifting (b) subsidence, 5. faults active in the Quaternary (and seismically active): (a) strike-slip, (b) normal and (c) reverse (d) probable. 
Table 2. Major tectonic events in the Serbian part of the Pannonian Basin and its southern margin during the Pliocene and Quaternary

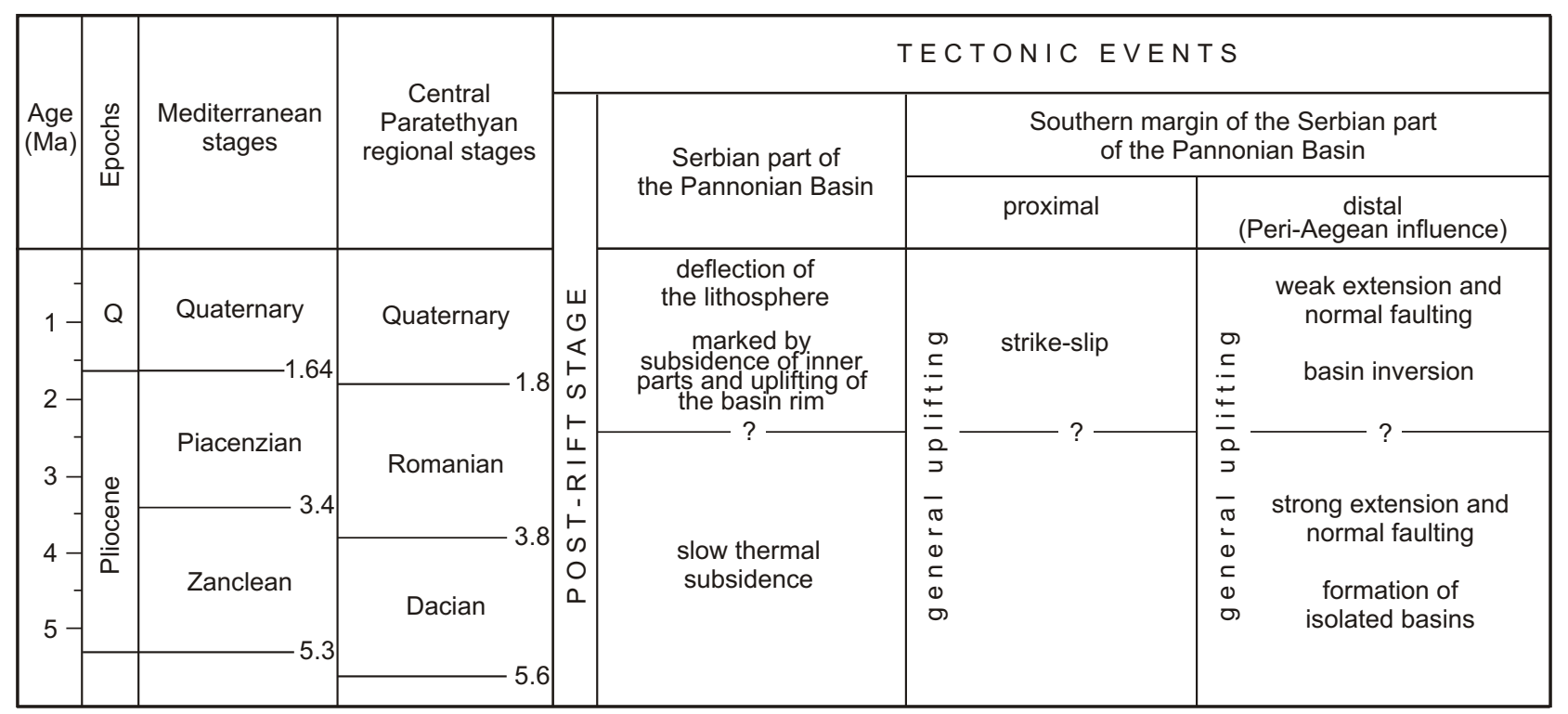

spreading influence, which could explain such kinematic characteristics of a small number of faults.

\section{Discussion}

6.1 Short review of the Neogene-Quaternary tectonic evolution of the SPPB and its rim

The Pannonian Basin, and so its Serbian part and southern margin, is a region in which extensional-synrift (the Ottnanghian-Karpatian-Badenian) and thermal-post-rift (the Sarmatian-Pliocene) subsidence became clear during the Neogene (Horváth, 1993). Such activity is a consequence of the tectonic escape of large crustal blocks from the Alpine collision zone, the subduction of the European lithosphere below those fragments, the rollback of the subducted slab and the collapse of an overthickened orogenic wedge behind the subduction front (Royden, 1988; Ratschbacher et al., 1991a, b; Horváth, 1993).

The SPPB and its southern margin, elongated approximately to NNW-SSE, are located in a distinctly compressive region in between the Adriatic and Moesian plates. In such an environment, a subsidential activity caused by extensional and thermal processes that led to thinning and the rheologic weakening of the lithosphere, developed during the Neogene. These processes were less distinguished on the southern periphery of the Serbian part of the Pannonian region. Due to its specific position (the basinal structural content being penetrating as a wedge far between the Dinaridic and CarpathoBalkanidic morphostructures), the region of the southern rim of the SPPB was already subjected to inversion from the beginning of the Badenian. The inversion was in a successive progress going from South to North, and it continued up into the Quaternary.

At the end of the Pliocene and the beginning of the Quaternary, a change in the tectonic regime occurred in the region of the Pannonian Basin (Horváth and Cloetingh, 1996). According to these authors, due to the ending of rollback and the progressive detachment of the subducted slab along the Carpathian Arch, the Intra-Carpathian basinal system was exposed to a strong compressive regime. It consequently led to generation of new tectonic relations within the Pannonian Basin domain, characterised by the increased subsidence of interior parts and the uplifting of the basin rim (Table 2). Such deformations were explained by a stress-induced deflection and folding of the weakened and less rigid Pannonian lithosphere into large-scale folds with wavelengths of around $400 \mathrm{~km}$. Such a model of geodynamic activity can also be recognised in the SPPB (the subsidence of inner parts including also peripheral "sinus" in the northern region of the Velika Morava Trough, and the uplifting of the rim, Figs. 5 and 9).

\subsection{Sources of stress and stress regimes}

In the Pannonian Basin, as well as in the majority of its southern rim, a compressive regime of a strike- slip type prevails (Gerner et al., 1995; Bada, 1999). One of the major sources of the compressive stress in this region (and thus in the SPPB and its southern rim) is the counterclockwise rotation of the Adriatic plate (Anderson and Jackson, 1987; Gerner et al., 1999; Bada et al., 1998; Bada, 1999). Due to such activity at the border zone of the Adriatic plate and the Dinaridic-Hellenidic orogene, high compression has been induced (“Adria push", Bada et al., 1998; Bada, 1999). A large 

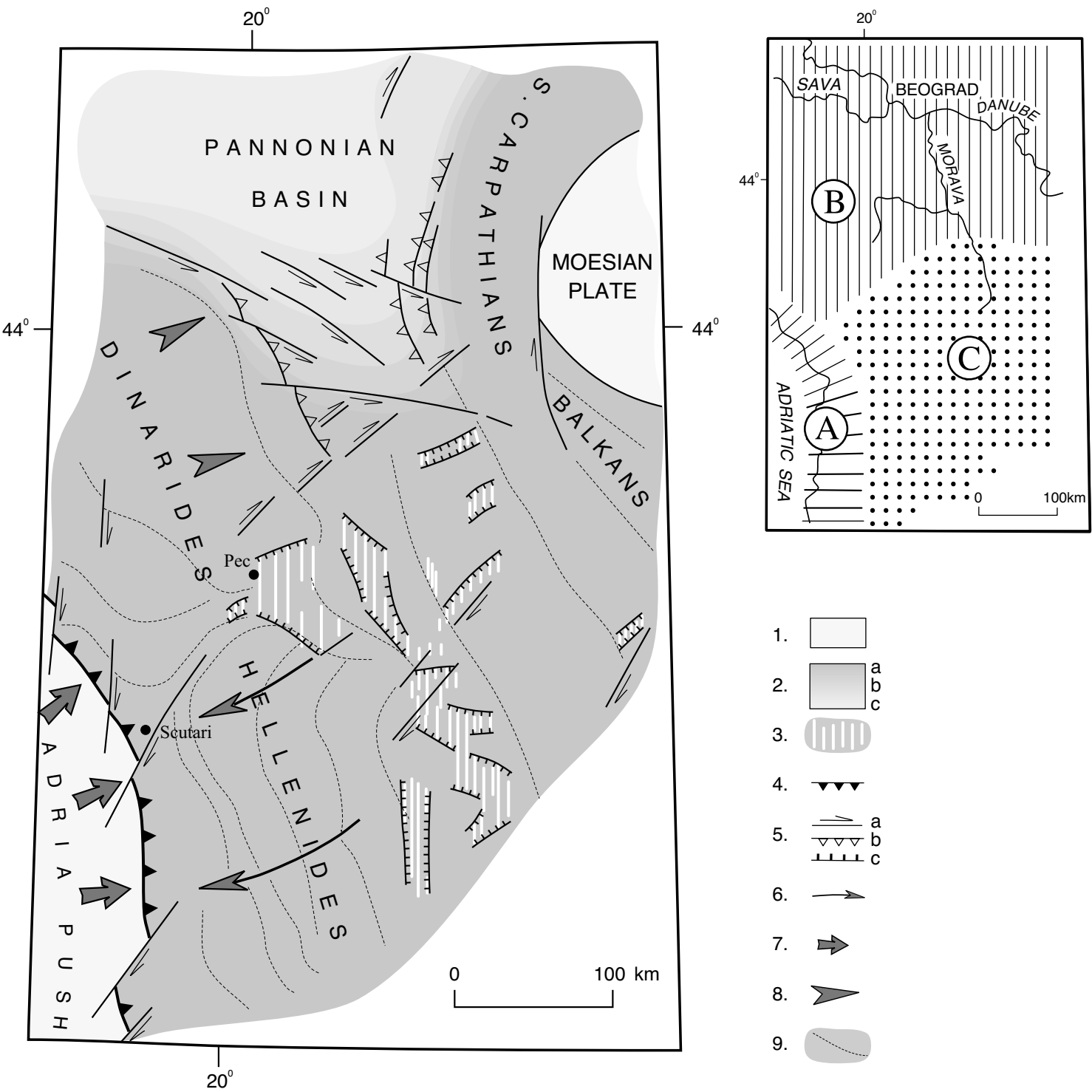

Fig. 10. Late Quaternary kinematics of large tectonic entities of the broader southern margin of the Pannonian Basin and a part of the Mediterranean. 1. Platform areas, 2. Alpine orogene (a) with relatively thick crust (and lithosphere), (b) transitional area between regions with thick and thinned orogene crust (and lithosphere) (area of major flexure in the Moho isobaths), (c) with thinned continental crust and rheologically weakened lithosphere, 3. Areas of Plio-Quaternary and Quaternary trough structures and gravitational faulting which were reactivated by the processes occurring during the Aegean collapse, 4. Convergent boundary between the orogene and the platform, 5. Major faults (a) strike-slip, (b) reverse and (c) normal, 6. The direction of rotation of the Hellenides, 7. Maximum horizontal stress directions in the convergent zone of the Adriatic microplate and the Dinarides-Hellenides, 8 . The direction of the tectonic transport of blocks in the area of nearest part of the southern margin of the Serbian part of the Pannonian Basin, 9. Boundaries of large Pre-Tertiary tectonic units of the Dinarides-Hellenides and Carpatho-Balkanides. Insert: areas with different contemporary stress regime (according to the idea of Bada, 1999): (A) - compressional, (B) - strike-slip and (C) - extensional (stress field).

amount of seismic energy has been released within that area. According to the calculations of Gerner et al. (1999), the amount of energy is several times greater than that released within the interior parts of the orogene and in the Pannonian region.

Another source of stress is genetically related to the Aegean orogenic collapse and is responsible only for the Quaternary deformations in the southernmost rim of the SPPB (south from the Scutari-Peć transverse). This is the area dominated by extension. Besides the Aegean Basin, large areas of the northern Peri-Aegean region in Greece, Bulgaria, Macedonia and Southern Serbia are also subjected to extension. In Serbia, the boundary between the two different stress fields, strike-slip and extension, is located somewhere in the distant parts of the southern Pannonian margin (Fig. 10, insert).

Finally, the important element that influences Quaternary tectonic activity within the Pannonian Basin and its rim (thus 
including its Serbian part) is the rheology of the lithosphere, i.e. its behaviour and inclination to deformation under conditions of increased intraplate compressive stress (Horváth and Cloetingh, 1996).

\subsection{Geodynamic implications and seismicity}

The expression of Quaternary tectonic activity in the SPPB and its southern rim, and consequently its seismicity, depended, in the first place, on the interplay of compressive stress (induced in the zone of the Adriatic plate/DinaridicHellenic orogene convergence) and the rheologic features of the lithosphere. The minor role belongs to the extensional processes initiated by the Aegean spreading.

As mentioned above, the main role is played by the compressive stress generated within the Adriatic plate/Dinarides convergence zone, by the Adria push mechanism (Gerner et al., 1999; Bada, 1999). This is the region where, in the relatively narrow Peri-Adriatic zone within the "Outer Dinarides", a major amount of stress has been released, which is marked by strong seismic activity. Maximum compressive stress has been transferred from the source area (Adriatic plate/Dinarides convergence zone) into the inner parts of the Dinarides and towards the SPPB, in a NE-SW direction (Rebaï et al., 1992; Gerner et al., 1999). However, judging by the fault plane solution for the earthquakes in the broader Kopaonik Mt. region in the territory of south-western Serbia, there is an eastward bending tendency of the compressive stress. This bending points to the tectonic transport of blocks within this area along a system of conjugated faults striking NE-SW (right strike-slip) and E-W (left strike-slip) toward the area exposed to strong Plio-Quaternary, and weak recent extension, south from the Scutari-Peć transverse (Metohija and Kosovo basins) (Fig. 10).

A major amount of transferred stress, in the form of moderate but frequent seismicity on the territory of Serbia, has been released on the boundary of two different crustal (and lithospheric) entities: the Pannonian and Dinaro-Carpathic (Fig. 10).

The Pannonian Basin region seen as a whole has a thinned crust and a relatively thin and rheologically weakened lithosphere. On the other side, in the surrounding orogenes domain, both the crust and the lithosphere are significantly thicker and also more rigid. A model worked out by Cloetingh and Burov (1996), which includes depth-dependant brittle ductile rheology, suggests that the forming of lithospheric folds with vertical undulations up to the order of kilometre is characteristic for such conditions. Horváth and Cloetingh (1996) are of the opinion that such structural phenomena, formed in the Quaternary, exist in the Pannonian Basin region. Therefore, in such conditions in the Pannonian Basin region, recent stress has been released by the deflection of the lithosphere (Horváth and Cloetingh, 1996) and, as it was suggested by Gerner et al. (1999), by aseismic creep manifestations.

The weakened lithosphere in the area of the SPPB could have also been subjected to deflection during the Quaternary, which is marked by the uplifting of the rim and the subsidence of the inner parts of the basin, as well as by low seismicity. However, within its rim, directly on the transition towards the rigid and thick crust and the lithosphere of the Dinarides in the southwest and the Carpathians in the east, the tectonic activity, which is marked by seismicity, becomes more intensive. In such conditions, mostly pre-existing faults were activated, and their kinematic characteristics are determined by the maximum compressive stress direction being oriented NE-SW, with a weak tendency to bend towards ENE-WSW.

The interesting thing is that the distant margin of the SPPB, i.e. the interior parts of the Dinarides (except for the Kopaonik region) and the Carpathians of Eastern Serbia, show lower seismicity than the parts near the AdriaticDinaridic margin. This is somehow understandable for the Carpathians of Eastern Serbia, considering their distance from the Adriatic/Dinaridic convergence zone as the main source of the recent compressive stress. However, such an explanation cannot be accepted for the Dinarides because they are closer to the source of the recent compressive stress than the direct southern rim of the Pannonian Basin. The explanation should be sought in the composition and interrelations of three large crustal (and lithospheric) entities: Adriatic, Dinaridic and Pannonian. The strongest Quaternary tectonic activity, marked by strong seismicity, occurs within the zones of contact between these entities. This is particularly the case in the Adriatic/Dinaridic contact zone where, by the Adria push mechanism (Gerner et al., 1999), SWvergent reverse displacements are activated along the faults striking NW-SE (Anderson and Jackson, 1987). The Pannonian lithosphere, due to its relatively high ductility and its position in rigid orogenic surroundings, reacts with deflection (Horváth and Cloetingh, 1996). The Dinaridic orogen would be expected to deform by faulting, having a rigid crust and lithosphere, but it does not show any such tendency, unless mobilised by some other processes, like the extension from the Aegean domain, for example. Nevertheless, the Dinarides represent a compact whole, which is subjected only to general uplifting, under compressive conditions. The transferred recent compressive stress has been released in the region northeast from the Adriatic/Dinaridic convergence zone, in the Dinarides/Pannonian Basin and Carpatho-Balkanides/Pannonian Basin boundary zones. Due to the deflective behaviour of the Pannonian lithosphere and the rigidity of the Dinarides and Carpatho-Balkanides, their boundary zones are the most susceptible to react to a compressive stress. Predominantly strike-slip faults have been activated (Figs. 9 and 10), which is followed by corresponding moderate, but frequent seismic activity.

The extension that is genetically related to the PlioceneQuaternary Aegean spreading only slightly influences the Quaternary deformations of the SPPB, mostly along its southernmost rim. The maximum extension direction in this region is identical to that in Northern Greece and Macedonia - NNW-SSE (Papazachos and Kiratzi, 1996). The influence of extensional processes within these regions during the 
Quaternary is much weaker than it was in the Pliocene. Such a conclusion is based on the fact that the inversion of the Pliocene basinal structures took place at the beginning of the Quaternary. Such activity is understandable considering the amplification of the compressive intraplate stress (originating in the Adriatic plate and Dinaridic-Hellenic orogene convergence zone) at the beginning of the Quaternary on the one hand, and the distance between these regions and the centre of maximum extension (The Aegean Sea) on the other.

The Aegean spreading and the extensional processes were accompanied by the westward and south- westward rotation of the Hellenic Arc during the Pliocene and Quaternary (Kissel and Laj, 1988; Kissel et al., 1995). According to these authors, rotation took place over the whole western part of the Hellenic Arc and the north-western out-arc segment up to the border zone of the Dinarides (s. str.) and the Helenides (up to the "Scutari-Peć transverse"). Such activity led to the inflection of the Dinaridic-Hellenic orogen within their boundary zone (Kissel et al., 1995), whereas on the convex side of the bend area, where high tension can be recognised, the basinal structures of Metohija and Kosovo were formed (Marović and Djoković, 1995) (Fig. 10). Rotation and westward translation of the Hellenides are very important for the Quaternary deformations of the north-western rim of Metohija and Kosovo, i.e. for the seismogenic region of southwestern Serbia, because it controls the tectonic transport of blocks within the region towards the East i.e. the area which is exposed to high tension (Marović et al., 1998a).

In the northernmost Peri-Aegean region, the extensional processes from the Aegean domain which have been already sufficiently weakened, activate normal faulting and weak subsidence of certain parts of the Neogene basins in the southern Pannonian margin (like the Leskovac and Niš basins), which is marked by weak seismicity. Focal mechanism for the event 15 (Fig. 7) points to a normal faulting in the region where the strike-slip compressional regime is dominant. It is hard to believe that the extensional processes in the Aegean and Peri-Aegean domain could generate such movements. The explanation should be sought elsewhere. We can even presume that a relatively thinned PeriPannonian crust (and lithosphere) on the territory of Serbia, squeezed between the rheologicly rigid Dinarides in the SW and Carpatho-Balkanides in the east, has been subjected to NNW-SSE stretching, followed by the activation of normal faults striking NE-SW. However, such conclusion is highly speculative and has to be proven.

\section{Conclusions}

It is obvious that the neotectonic activity in the SPPB and its southern margin has been controlled mainly by

(1) increased compression induced at the border zone of the Adriatic plate and the Dinarides (Adria push),

(2) the crust composition and the rheologic features of the lithosphere as a whole, and finally, to a lesser extent
(3) extensional processes from the Aegean domain.

In the Pannonian region, maximum horizontal intra-plate stress has been released by the deflection of the rheologically weakened Pannonian lithosphere, resulting in the subsidence of the interior parts of the basin and the uplifting of its rim. Such activity generates low seismicity. In the border zone of the Pannonian lithosphere and the rigid entities of the Dinarides and the Carpathians of Eastern Serbia, the Quaternary stress has been released by shearing along faults of predominantly strike-slip kinematic type. This results in frequent but moderate-magnitude earthquakes. The Dinarides (except for the border zone towards the Adriatic plate) and the Carpatho-Balkanides, although rigid, are compact bodies which have not been subjected, during the Quaternary, to any stronger deformation, except general uplifting. That is why they show a low seismic activity. The exceptions are only those parts which belong to the Aegean extension influence zone, where normal faulting is present, resulting in weak-tomoderate seismicity.

Acknowledgements. The authors gratefully acknowledge Dr. G. Bertotti as well as two anonymous reviewers for their comments and relevant suggestions which have helped to improve the manuscript. Many thanks also to Dr. Gabor Bada and Dr. F. Horváth for helpful comments on an early version of this paper. This study was supported by Seismological Survey of Serbia.

\section{References}

Anderson, H. and Jackson, J.: Active tectonics of the Adriatic region. Geophys. J. Roy. Astron. Soc., 91, 937-983, 1987.

Bada, G.: Cenozoic stress field evolution in the Pannonian basin and surrounding orogens. Inferences from kinematic indicators and finite element stress modeling. PhD thesis, Vrije Universiteit, Amsterdam, 204 p., 1999.

Bada, G., Cloetingh, S. A. P. L., Gerner, P., and Horváth, F.: Sources of recent tectonic stress in the Pannonian region: inferences from finite element modeling. Geophys J. Int., 134, 87-102, 1998.

Becker, A.: Contemoporary state of stress and neotectonic deformation in the Carpathian-Pannonian region. Terra Nova, 5, 375388, 1993.

Bergerat, F.: Evolution des méchanismes d'extension dans le bassin Pannonien. Geodin. Acta, 2, 89-98, 1988.

Bergerat, F., Geyssant, J., and Lepvrier, C.: Neotectonic outline of the intra-Carpathian basins in Hungary. Acta Geol. Hung., 27, 237-249, 1984.

Cloetingh, S. A.P.L. and Burov, E.: Thermomechanical structure of European continental lithosphere: constraints from rheological profiles and EET estimates. Geophys. J. Int., 124, 695-723, 1996.

Cloetingh, S. A.P.L., Kooi, H., and Groenewoud, W.: Intraplate stress and sedimentary basin evolution. Am. Geophys. Union, Geophys. Monogr., 48, 1-16, 1989.

Csontos, L.: Tertiary tectonic evolution of the Intra-Carpathian area: a review. Acta Vulcan., 7, 1-13, 1995.

Csontos, L., Tari, G., Bergerat, F., and Fodor, L.: Evolution of the stress fields in the Carpatho-Pannonian area during the Neogene. Tectonophysics, 199, 73-91, 1991. 
Csontos, L., Nagymarosy, A., Horváth, F., and Kovác, M.: Tertiary evolution of the Intra-Carpathian area: a model. Tectonophysics, 208, 221-241, 1992.

Demenitskaya, R. M.: Crust and mantle of the Earth, Nedra, 1-280 (in Russian), 1967.

Djoković, I., Marović, M., Radovanović, S., Trivić, B., Cupković, T., and Kovacević, V.: Recent ruptured structures in the area of Kopaonik. Symp. Geology and Metallogeny of the Kopaonik Mt., 73-78 (in Serbian with English abstract), 1995.

Gerner, P., Dövényi, P., Horváth, F., and Müller B.: State of recent stress and seismotectonics in the Pannonian basin and surrounding area. Terra Abstracts, 7, p. 123, 1995.

Gerner, P., Bada, G., Dövényi, P., Müller, B., Onescu, M. C., Cloetingh, S. A.P.L., and Horváth, F.: Recent tectonic stress and crustal deformation in and around the Pannonian basin: data and models, in: Durand, B., Jolivet, L., Horváth, F., and Séranne, M. (Eds.): The Mediterranean basins: Tertiary extension within the Alpine orogen. Geol. Soc. Lond. Spec. Publ., 156, 269-294, 1999.

Glavatović, B.: Mohorovičić Discontinuity Distribution Determination by Inversion of the Regional Bouguer Gravity Anomaly using the QR-algorithm and Spline-interpolation. Acta Seismologica Iugoslavica, 14, 1-95 (in Serbian with English résumé), 1988.

Glavatović, B.: The Map of the Position of the Mohorovičić Discontinuity on the Territory of Serbia. Holdings of the Seismological Institute of Serbia, 1989.

Grubić, A.: Yugoslavia - An Otline of Geology of Yugoslavia. Guide Book, No. 15, 26th International Geolog. Congress, 97p, Paris, 1980.

Gutdeutsch, R. and Aric, K.: Seismicity and neotectonics of the East Alpine-Carpathian and Pannonian area, in: Royden, L. H. and Horváth, F. (Eds.): The Pannonian Basin, a Study in Basin Evolution. Am. Assoc. Pet. Geol. Mem., 45, 183-194, 1988.

Horváth, F.: Neotectonics of the Pannonian basin and the surrounding mountain belts: Alps, Carpathians and Dinarides. Ann. Geophys., 2, 147-154, 1984.

Horváth, F.: Structural evolution of the Pannonian Basin: A progress report. Acta Geol. Geoph. Hung. 25(3-4), 243-255, 1990.

Horváth, F.: Towards a mechanical model for the formation of the Pannonian basin. Tectonophysics, 226, 333-357, 1993.

Horváth, F. and Royden, L.: Mechanism for the formation of intraCarpathian Basins: a review. Earth Evol. Sci., 1, 307-316, 1981.

Horváth, F. and Rumpler, J.: The Pannonian basement: extension and subsidence of an Alpine orogen. Acta Geol. Hung., 27, 229235, 1984.

Horváth, F. and Cloetingh, S. A. P. L.: Stress-induced late-stage subsidence anomalies in the Pannonian basin. Tectonophysics, 266, 287-300, 1996.

Karamata, S. and Krstić, B.: Terranes of Serbia and Neighbouring areas. In: Knežević, V. and Krstić, B. (Eds): Terranes of Serbia, 25-40, 1996.

Kissel, C. and Laj, C.: The Tertiary geodynamic evolution of the Aegean arc: paleomagnetic reconstruction. Tectonophysics, 146, 183-201, 1988.

Kissel, C., Speranza, F., and Milićević, V.: Paleomagnetism of external southern and central Dinarides and northern Albanides: implications for the Cenozoic activity of the Scutari-Peć transverse zone, J. Geophys. Res., 4, 199-221, 1995.

Linzer, H. G., Frisch, W., Zweigel, P., Girbacea, R., Hann, H. P., and Moser, F.: Kinematic evolution of the Romanian Carpathians,
Tectonophysics, 297, 133-156, 1998.

Louvari E. K. and Kiratzi, A. A.: RAKE: A Windows program to plot earthquake focal mechanisms and the orientation of principal stresses. Computers and Geosciences, 23, 851-857, 1997.

Marović, M. and Djoković, I.: Neotectonic Activity in Macva, Pocerina and Kolubara-Tamnava Basin. Ann. Géol. Penins. Balk., 53, 189-197, 1989.

Marović, M. and Djoković, I.: General neotectonic features of the Velika Morava Trough (SE part of the Pannonian Basin). Bull. INQUA Neotec. Commiss. 13, p. 32, 1990.

Marović, M. and Djoković, I.: Neotectonic Activity of the ScutariPeć General Area. Ann. Géol. Penins. Balk., 59/2, 23-43, 1995.

Marović, M., Djoković, I., and Nedeljković, S.: Neotectonics and Seismicity of Pomoravlje and Adjoining Regions. Ann. Géol. Penins. Balk., 58/2, 25-52, 1994.

Marović, M., Djoković, I., Knežević, S, Rundić, Lj., Mitrović, S., Šumar, M., and Toljić, M.: Principal Geodynamic stages and Paleogeographic Changes in South-eastern Peripannonian Realm of Neogene and Quaternary. XV Congr. CBGA Geol. Soc. Greece, Sp. publ. N. 4., 69-73, 1995.

Marović, M., Djoković, I., and Milićević, V.: Structural Geometry and Kinematics of Neoalpine Lithospheric Extension in Vojvodina part of Pannonian Basin. Ann. Géol. Penins. Balk., 60/2, 79-97, 1996.

Marović, M., Djoković, I., Pešić, L., Toljić, M., Vojvodić, V., and Gerzina, N.: Pliocene-Quaternary Tectonic Activity of Terranes of Serbia: Seismological Implications. Proc. 1. Cong. of Yug. Geophys., 446-454, 1998a.

Marović, M., Djoković, I., and Toljić, M.: Genesis of the Neotectonic Structures of Serbia. Ann. Géol. Penins. Balk., 62, 25-45, 1998b.

Müller, B., Zoback, M. L., Fuchs, K., Mastin, L., Gregersen, S., Pavoni, N., Stephansson, O., and Ljunggren, C.: Regional pattern of tectonic Stress in Europe. J. Geophys. Res., 97, 11783 $11803,1992$.

Papazachos, C. B. and Kiratzi, A. A.: A detailed study of the active crustal deformation in the Aegean and surrounding area. Tectonophysics, 253, 129-153, 1996.

Peresson, H. and Decker, K.: From extension to compression: Late Miocene stress inversion in the Alpine-Carpathian-Pannonian transition area. Mitt. Ges. Geol. Bergbaustud., 41, 71-86, 1996.

Philip, H.: Plio-Quaternary evolution of the stress field in Mediterranean zones of subduction and collision. Ann. Geophys., 5B/3, 301-320, 1987.

Procházkova, D. and Roth, Z.: Seismotectonics of central Europe. Contr. Geophys. Inst. Slov. Acad. Sci., 23, 79-103, 1993.

Praus, O., Pečova, J., Petr, V., Babuška, V., and Plomerová, J.: Magnetotelluric and seismological determination of lithosphereastenosphere transition in Central Europe. Phys. Earth Planet. Inter., 60, 212-228, 1990.

Radovanović, S.: A Crustal velocity model of the Vardar Zone Developed from the Travel-Time Inversion of Shallow Eartquakes Body Waves. MA thesis, Belgrade, 66p, 1995.

Rakić, M.: Pleistocen Srema i Banata, in: Petković, K. (Ed.): Geologija Srbije II-3, Stratigrafija-kenozoik, 399-405 (in Serbian), 1977.

Ratschbacher, L., Merle ,O., Davy, P., and Cobbold, P.: Lateral extrusion in the Eastern Alps, part 1: Boundary conditions and experiments scaled for gravity. Tectonics, 10, 245-256, 1991a.

Ratschbacher, L., Frisch, W., Linzer, H. G., and Marle, O.: Lateral extrusion in the Eastern Alps, part 2: Structural analysis. Tectonics, 10, 257-271, 1991b. 
Ratschbacher, L., Linzer, H. G. Moser, F., Strusievicz, R. O., Bedelan, H., Har, N., and Mogos, P. A.: Cretaceous to Miocene thrusting and wrenching along the central South Carpathians due to a corner effect collision and orocline formation, Tectonics 12 , 855-873, 1993.

Rebaï, S., Philip, H., and Taboada, A.: Modern tectonic stress field in the Mediterranean region: evidence for variation stress directions at different scales. Geophys. J. Int., 110, 106-140, 1992.

R onai, A.: Size of Quaternary movements in Hungary's area. Acta Geol. Hung., 18, 39-44, 1974.

Royden, L. H.: Late Cenozoic tectonics of the Pannonian basin system, in: Royden, L. H., and Horváth, F. (Eds.): The Pannonian Basin, a Study in Basin Evolution. Am. Assoc. Pet. Geol. Mem., 45, 27-48, 1988.

Royden, L. H., Horváth, F., and Burchfiel, B. C.: Transform faulting, extension and subduction in the Carpatho-Pannonian region. Geol. Soc. Am. Bull., 73, 717-725, 1982.

Royden, L. H., Horváth, F., Nagymarosy, A., and Stegena, L.: Evolution of the Pannonian Basin System. 2. Subsidence and thermal history. Tectonics, 2, 91-137, 1983.

Sclater, J. G., Royden, L., Horváth, F., Burchfiel, B. C., Semken, S., and Stegena, L.: The formation of the Intra-Carpathian basins as determined from subsidence data. Earth Planet. Sci. Lett., 51, 139-162, 1980.

Starčević, M.: The Map of Moho surface 1:2000 000, in: Dimitrijević, M. D. (Ed.): Geol. Atlas of Serbia, 4, 5, Foundation for Geol. Investigation of Rep. Serbia \& GEMINI, Belgrade, 1995.

Starčević, M. and Djordjević, A.: Geophysical characteristics of Danube Gorges. Geology of Djerdap Area, Spec. ed. Geoinstitute, 25, 153-154, 1997.

Stegena, L., Géczy, B., and Horváth, F.: Late Cenozoic evolution of the Pannonian Basin. Tectonophysics, 26, 71-90, 1975.

Tari, G., Horváth, F., and Rumpler, J.: Styles of extension in the Pannonian Basin. Tectonophysics, 208, 203-219, 1992.

The Map of the Recent Vertical Displacements of Earth's Crust in Yugoslavia 1:2 500 000, Federal Geodesy Survey, 1972.

The Geologic Map of SFRY 1:500000, Federal Geological Institute, 1970.

Zoback, M. L.: First- and second-order of stress in the lithosphere: the World Stress Map Project. J. Geophys. Res., 97, 1170311 728, 1992.

Zweigel, P., Ratchbacher, L., and Frisch, W.: Kinematics of an arcuate fold-thrust belt: the Southern Eastern Carpathians (Romania), Tectonophysics 297, 177-207, 1998. 